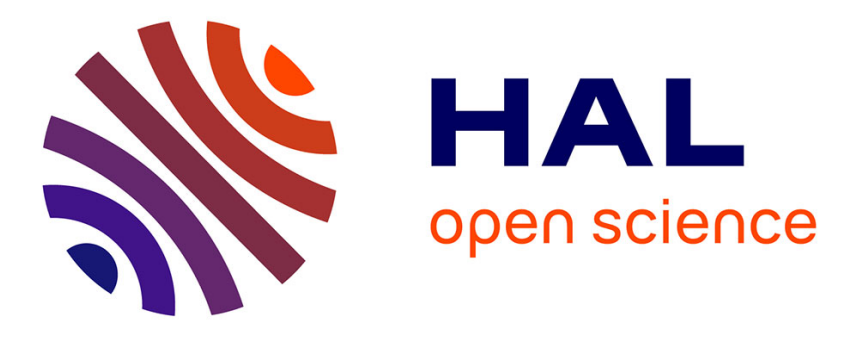

\title{
Surface Plasma Treatment (Ar/CF4) Decreases Biofouling on Polycarbonate Surfaces
}

Fabienne Fä̈, Fabienne Poncin-Epaillard, Tiffany Le Norcy, Isabelle Linossier, Karine Réhel

\section{- To cite this version:}

Fabienne Faÿ, Fabienne Poncin-Epaillard, Tiffany Le Norcy, Isabelle Linossier, Karine Réhel. Surface Plasma Treatment (Ar/CF4) Decreases Biofouling on Polycarbonate Surfaces. Surface Innovations, 2021, 9 (1), pp.65-76. 10.1680/jsuin.20.00026 . hal-02993124

\section{HAL Id: hal-02993124 \\ https://hal.science/hal-02993124}

Submitted on 6 Oct 2021

HAL is a multi-disciplinary open access archive for the deposit and dissemination of scientific research documents, whether they are published or not. The documents may come from teaching and research institutions in France or abroad, or from public or private research centers.
L'archive ouverte pluridisciplinaire HAL, est destinée au dépôt et à la diffusion de documents scientifiques de niveau recherche, publiés ou non, émanant des établissements d'enseignement et de recherche français ou étrangers, des laboratoires publics ou privés. 


\section{Surface plasma treatment $\left(\mathrm{Ar} / \mathrm{CF}_{4}\right)$ decreases biofouling on polycarbonate surfaces}

Fabienne Faÿ, PhD, Assistant Professor, Université Bretagne Sud, EA 3884, Laboratoire Biotechnologie et Chimie Marine, IUEM, Lorient, France

Fabienne Poncin-Epaillard, PhD, Professor, Institut des Molécules et Matériaux du Mans, UMR Le Mans Université, CNRS 6283, Le Mans, France

Tiffany Le Norcy, PhD, Researcher, Université Bretagne Sud, EA 3884, Laboratoire Biotechnologie et Chimie Marine, IUEM, Lorient, France

Isabelle Linossier, PhD, Professor, Université Bretagne Sud, EA 3884, Laboratoire Biotechnologie et Chimie Marine, IUEM, Lorient, France

Karine Réhel, PhD, Professor, Université Bretagne Sud, EA 3884, Laboratoire Biotechnologie et Chimie Marine, IUEM, Lorient, France

*Fabienne Faÿ, PhD

Université Bretagne Sud, EA 3884, Laboratoire Biotechnologie et Chimie Marine, BP92216, 56321 Lorient Cedex, France, fabiene.fay@univ-ubs.fr, 0297874626

\section{Abstract:}

The purpose of this study was to examine the impact of hydrophobicity, surface chemistry, and topography on bacterial and microalgal adhesion. To this end, the effects of surface plasma treatments (Argon and Tetrafluorocarbon) of polycarbonate substrates on bioadhesion were investigated in vitro. Surfaces were characterized by goniometry, atomic force microscopy (AFM), and X-ray photoelectron spectroscopy (XPS). Two marine bacterial strains, a hydrophobic Pseudoalteromonas sp. 5M6 and a hydrophilic Paracoccus sp. 4M6 and two microalgae (Cylindrotheca closterium and Porphyridium purpureum) involved in marine biofouling were selected. Their adhesion on the substrates was observed and quantified using confocal laser scanning microscopy-microfluidic flow-cells. It was demonstrated that the combination of three parameters, namely surface energy, fluorination, and nanotopography, significantly decreases the adhesion of three micro-organisms out of four (Pseudoalteromonas sp. 5M6, Cylindrotheca Closterium, and Porphyridium purpureum) whereas one parameter on its own is insufficient.

Keywords: Antifouling, Adhesion, Anti-microbial, plasma processing, polymeric materials, surface chemistry, surface energy, surface roughness. 


\section{Introduction}

Polycarbonate (PC) finds extensive applications, ranging from sensor on boats, due to its toughness, optical clarity, durability and the possibility of blending it with other polymers ${ }^{1}$. However, as for most polymeric surfaces immersed in seawater, PC is colonized by various prokaryotes and eukaryotes cells ${ }^{1,2}$. The development of biofilms starts with adhesion of the cells to the surface. This phenomenon, called bioadhesion, is caused by interactions between abiotic surfaces and biological cells ${ }^{3}$ and engenders serious drawbacks. The development of bacterial and microalgal biofilms, called microfouling, induces frictional resistance ${ }^{4}$, reduced vessel performance, and increase of structural fatigue ${ }^{4,5,6}$. Prolonged exposure of the sensors to seawater compromises their effectiveness, thus making early detection of performance failure critical $^{7}$. Moreover, the presence of microfouling significantly enhances the settlement of invertebrate larvae (i.e. macrofouling) ${ }^{8}$. All these effects generate high maintenance costs ${ }^{9}$. Therefore, controlling cell adhesion to the material remains a challenge.

Physico-chemical characteristics (charge, hydrophobicity) of cells play an essential role in bioadhesion $^{10,11}$. It has been demonstrated that generally, bacterial cells adhere better to hydrophobic, non-polar, and positively charged surfaces ${ }^{12,13}, 14$. However, findings are conflicting $^{15,16}$. In the case of diatoms, the cell surface hydrophobicity is one of the main parameters that promote the initial to surfaces ${ }^{17}$. However, some studies have shown that the large amount of extracellular polymeric substances (EPS) secreted by cells plays a significant part that can dominate the surface interactions of microalgae ${ }^{17,18,19}$.

The characteristics of material properties that affect bioadhesion involve chemical composition, surface energy, hydrophobicity, topography, surface roughness, and charge ${ }^{20,21}$. Surface treatments to modulate bioadhesion (e.g. laser surface treatment, lithography, contact printing, radiation grafting, electron beam process) have been reviewed in Waugh et al. ${ }^{22}$. Among them, plasma treatments have been used in the conception of surfaces to study bacterial adhesion on some polymeric surfaces ${ }^{23}$. The use of plasma for surface modifications is an attractive alternative to the more conventional wet organic chemistry because the process is free of toxic solvents or catalysts ${ }^{25,26}$. Moreover, plasma processing for surface modification is controllable, inexpensive, and applicable to polymers ${ }^{26}$. 
Plasmas such as argon $(\mathrm{Ar})$, dioxygen $\left(\mathrm{O}_{2}\right)$, nitrogen $\left(\mathrm{N}_{2}\right)$, or tetrafluoromethane $\left(\mathrm{CF}_{4}\right)$ induce the attachment of non-polar or polar functional groups such as hydroxyl, carbonyl, amino or fluorinated groups to the surfaces. These modifications alter the interactions with biological molecules and cell adhesion ${ }^{23,27}$. For example, Ar-treated polyethylene (PE) has been shown to reduce S. epidermidis adhesion ${ }^{28} . \mathrm{O}_{2}$ and $\mathrm{N}_{2}$ are the plasmas often used to modify the hydrophobicity of polymeric surfaces (PC, polypropylene (PP), polystyrene (PS), polyterephtalate ethylene $(\mathrm{PET}))^{25,29}$. However, a few studies deal with the use of $\mathrm{CF}_{4}$ plasma to treat polymer surfaces such as polydimethylsiloxane $(\mathrm{PDMS})^{31}$, PS and $\mathrm{PP}^{24,31}$, or polymethyl methacrylate (PMMA) ${ }^{32}$. The use of a $\mathrm{CF}_{4}$ plasma to fluorinate polymeric surfaces has created a hydrophobic layer modulating protein absorption, bacterial adhesion, and inflammatory cell response $\mathrm{e}^{24,30,31,32}$. However, no data deal with bacterial and microalgae attachment to $\mathrm{Ar} / \mathrm{CF}_{4}$-treated PC surfaces.

In this study, the adhesion of two marine bacteria, Paracoccus sp. 4M6 and Pseudoalteromonas sp. 5M6 related to the class of alphaproteobacteria (Rhodobacterales order) and gammaproteobacteria (Alteromonadal order) respectively and two microalgae (Cylindrotheca Closterium and Porphyridium Purpureum) on Ar/ $\mathrm{CF}_{4}$-treated PC surfaces is examined. The four micro-organisms under investigation have been isolated on polymeric surfaces including antifouling coatings immersed in seawater ${ }^{33,34,35}$. They are representative of the seawater environment and are involved in surface colonization ${ }^{36}$. For example, the Rhodobacterales (Paracoccus sp. 4M6) have been shown to be dominant and ubiquitous primary surface colonizers $^{33,37}$. Bacteria from the genus Pseudoalteromonas have been indicated to be strong settlement inducers for the larvae of various marine invertebrates ${ }^{38}$. Cylindrotheca spp. (Bacillariophyceae, i.e. diatoms) was reported as the dominant species on fouling release and antifouling coatings ${ }^{34,39}$. The four strains can develop biofilm in laboratory tests ${ }^{40,41,42}$, which is why they are currently used as model micro-organisms in the study of molecules or coatings with antibiofilm activities ${ }^{43,44,45,46,47}$. In these studies, $P$. purpureum is particularly notable due to its resistance to anti-biofilm molecules. Nevertheless, no data on their sensitivity to surface hydrophobicity, chemistry, and nanotopography are known. Only the impact of microtopography on C. Closterium is reported ${ }^{48,49,50}$.

The twofold purpose of the study is i) to evaluate the impact of three surface parameters, namely hydrophobicity, fluorination, and nanotopography, on marine bacterial and microalgae adhesion, and ii) to propose a surface that effectively decreases marine bioadhesion. 


\section{Experimental}

\subsection{Surface preparation}

Polycarbonate (PC) films (6 $\mu \mathrm{m}$ thickness) were purchased from Goodfellow (Lille, France). They were homogeneously applied on a glass slide $(24 \times 50 \mathrm{~mm})$ with silicone glue (Clear Super Silicone, 3M, Cergy Pontoise, France) around the edges. After the glue curing, the films were washed with ethanol.

\subsection{Plasma modifications}

Plasmas composed of $\mathrm{Ar}$ or a mixture of $\mathrm{Ar}$ and $\mathrm{CF}_{4}$ were chosen to modulate the surface chemistry by combining oxidative effects (Ar treatment) with fluorination $\left(\mathrm{CF}_{4}\right.$ treatment). The plasma reactor is a capacitively coupled RF reactor. The excitation module was a RF generator at $13.56 \mathrm{MHz}$ (Sairem $0-600 \mathrm{~W}$ ), with a matching box adjusting the generator impedance to limit the reflected power. The reactor was a $310 \mathrm{~mm}$ x $255 \mathrm{~mm}$ rectangular aluminium chamber with its cathode linked to the generator and the anode grounded. The pumping stage was composed of a primary pump (CIT-ALCATEL $\mathrm{n}^{\circ} 2010$ SD) and a turbomolecular pump (ALCATEL ATP 80/100). The pressure was measured with a Pirani gauge (ACC 1009). The ultimate pressure was around $10^{-6}$ mbar. Mass flowmeters (Aera FC 7700 CDC) controlled the amount of injected gas. The distance between the sample and the cathode was $120 \mathrm{~mm}$. The chosen gases were supplied by AirLiquide and Messer (purity > $99 \%$ ). The plasma-treatment was examined as a function of the gas proportions $\left(\mathrm{Ar} / \mathrm{CF}_{4}(\% / \%): 100 / 0,12 / 88\right.$, or $\left.88 / 12\right)$ while the other parameters were fixed (power discharge $P=50 \mathrm{~W}$, flow $\mathrm{D}_{\mathrm{Ar}}=5 \mathrm{sccm}, \mathrm{D}_{\mathrm{CF} 4}=37 \mathrm{sccm}$ $(12 \% / 88 \%)$, and duration $t=10 \mathrm{~min})$.

\subsection{Characterization of surfaces}

The plasma-treated PC films were analyzed with an XPS instrument (Kratos Axis Nova, UK) located at the Institut des Matériaux of Nantes (France) with a monochromatic Al Ka beam at the electron emission angle of $90^{\circ}$ relative to the sample surface. The pass energies for survey spectra were $80 \mathrm{eV}$ (increment $=0.5 \mathrm{eV}$ ) and $20 \mathrm{eV}$ (increment $=0.1 \mathrm{eV}$ ) for high resolution. The full width at half-maximum (FWHM) for the Gaussian peaks was maintained as a constant value for all atomic components, but depending on the layer type, it varied from 1.4 to $1.8 \mathrm{eV}$. The high resolution fitting accuracy was $5 \%$.

The surface hydrophobicity measurements of the plasma-treated PC substrates were carried out using a goniometer (Ramé Hart Inc. goniometer) with $3 \mu 1$ high purity water drops (MilliQ 
Water System, resistivity $18 \mathrm{M} \Omega \mathrm{cm}^{-1}$ ) and diiodomethane drops (Sigma-Aldrich France, $\geq$ $99 \%)$. At least five drops of each liquid were deposited for each sample surface and each parameter under investigation. Measurements were run on both sides of the drop. In order to evaluate the hydrophobicity of surfaces, the surface energy was calculated using the OwensWendt method with the followed equations:

1.

$$
\gamma_{L}(1+\cos \theta)=2 \sqrt{\gamma_{S}^{D}+\gamma_{L}^{D}+2 \sqrt{\gamma_{S}^{P}+\gamma_{L}^{P}}}
$$

where $\gamma_{L}$ is the surface free energy of the measured liquid, $\gamma_{S}$ is the surface free energy of solids in vacuum, $\theta$ is the contact angle measured on the surface, $\gamma_{S}^{D}$ is the dispersive component of the materials, $\gamma_{S}^{P}$ is the polar component of the materials, $\gamma_{L}^{D}$ is the dispersive component of liquid, and $\gamma_{L}^{P}$ is the polar component of liquid.

2.

$$
\gamma_{S}=\gamma_{S}^{P}+\gamma_{S}^{D}
$$

where $\gamma_{S}$ is the surface free energy of materials.

An atomic force microscope (AFM) (Bruker-Innova) working in the tapping mode was used to study the surface morphology of each sample and to analyze the surface roughness at nanometer scale. Typically, the surface morphology of $5 \mu \mathrm{m}$ x $5 \mu \mathrm{m}$ area near the center of each sample was observed. The images were processed using Gwiddion software for the subtraction of the polynomial background and the calculation of the average roughness $\left(\mathrm{R}_{\mathrm{a}}\right)$ and the root mean squared $\left(\mathrm{R}_{\mathrm{ms}}\right)$.

\subsection{Micro-organisms, culture conditions}

Two Gram negative marine bacteria, Paracoccus sp. 4M6 and Pseudoalteromonas sp. 5M6 were selected. They are pioneer bacteria involved in substrata bioadhesion in seawater. They were isolated from the Gulf of Morbihan (France) and characterized ${ }^{33}$. Strains were cultivated at $20^{\circ} \mathrm{C}$ using Zobell media (Artificial SeaWater (ASW) $30 \mathrm{~g} / \mathrm{L}$, Tryptone $4 \mathrm{~g} / \mathrm{L}$, Yeast Extract $1 \mathrm{~g} / \mathrm{L}$ (Difco, Becton, Dickinson and Company)). Bacterial cultures were incubated at $2 \times 10^{7}$ $\mathrm{cfu} / \mathrm{mL}$ for 48 hours under agitation. 
Two axenic microalgal strains, Cylindrotheca closterium (AC-170) (Bacillariophyceae, (Ehrenberg) Reimann \& Lewin) and Porphyridium purpureum (AC-122) (Porphyridiophyceae (Bory) Drew \& Ross) were obtained from Algobank (Biological Resource of the University of Caen, Normandie, France). The axenization was realized by treatment with a mixture of three antibiotics (Sigma): chloramphenicol $(100 \mu \mathrm{g} / \mathrm{mL})$, penicillin $(1000 \mu \mathrm{g} / \mathrm{mL})$, and streptomycin (500 $\mu \mathrm{g} / \mathrm{mL}$ ) for 24 hours. Both strains were grown in sterile ASW medium with Guillard's F/2 (Sigma). Guillard's F/2 was added after sterilization and the culture medium was stored at $4{ }^{\circ} \mathrm{C}$ before use. Erlenmeyer flasks were maintained under controlled illumination of 250 $\mu$ mol.photons. $\mathrm{m}^{-2} \cdot \mathrm{s}^{-1}$ with fluorescent lamps (Philips Master TL5 HO 54W/840 1SL/20) at $20^{\circ} \mathrm{C}$ for 2 weeks with a 12:12 h light-dark cycle in a Hélios 600 phytotron (Cryotec, SaintGély-du-Fesc, France). Cultures were initially started with about $10^{3}$ cell.mL $\mathrm{mL}^{-1}$. After 2 weeks, both strains were in stationary phase.

\subsection{Bioadhesion test}

Experiments were realized using flow-cells ${ }^{41}$. First, the system was assembled by sticking samples. After sterilization of the system using a flow of bleach solution (2.6\% active chlorine, $\mathrm{pH}=11.5$ ) for 1 hour at $330 \mu \mathrm{L} / \mathrm{min}$, a flow of ASW (30 g/L) or ASW+F/2 Guillard (2\%) (for bacteria and microalgae respectively) was activated at $330 \mu \mathrm{L} / \mathrm{min}$ for 2 hours to clean and prepare the system for the bacterial or microalgae injection. Next, the sterilization of the system was verified: no micro-organism (bacteria or microalgae) was found.

Each channel was inoculated with $300 \mu \mathrm{L}$ of bacterial cultures diluted in ASW medium $\left(4 \times 10^{7}\right.$ $\mathrm{cfu} / \mathrm{mL})$ or $300 \mu \mathrm{L}$ of 2 weeks diatoms cultures in $\mathrm{F} / 2$ medium $\left(10^{5}\right.$ cells $\left./ \mathrm{mL}\right)$. The flow cells were placed upside down to facilitate cell adhesion on the polycarbonate. For bacterial and microalgal adhesion, the incubation temperature was $20^{\circ} \mathrm{C}$. For microalgal adhesion, a 12:12 $\mathrm{h}$ light-dark cycle was maintained. The incubation time was 2 hours for the bacteria strains and 24 hours for the microalgae. Next, a flow at $120 \mu \mathrm{L} / \mathrm{min}$ was activated for 30 minutes to remove free bacteria and microalgae. Once again, the sterile condition of the system was verified: only inoculated species were functional and identified by counting on agar plates.

The adhesion of the cells was observed with confocal laser scanning microscopy (Zeiss, LSM 710 ) by using a $40 \mathrm{X}$ oil immersion objective for bacteria and $20 \mathrm{X}$ air objective for microalgae. Adhered bacteria were observed with Syto9 nucleic acid stain $(5 \mu \mathrm{M}, \square$ excitation $=488 \mathrm{~nm}$, 
$\left.\lambda_{\text {emission }}=493-543 \mathrm{~nm}\right)$. Adhered microalgae were observed by their fluorescence $\left(\lambda_{\text {excitation }}=\right.$ $\left.633 \mathrm{~nm}, \lambda_{\text {emission }}=638-688 \mathrm{~nm}\right)$.

The percentage of bacterial coverage on surfaces was determined with a JAVA program (Université Bretagne Sud, Lorient, France). This program determines a percentage between black (the entire area observed) and green pixels (representing bacterial cells). Results are the average of 27 random observations. Experiments were realized with three independent cultures. The three channels of each flow cell were inoculated, and three random observations were realized per channel.

The number of microalgae adhered on the surface was visually counted and presented as the number of cells by $\mathrm{cm}^{2}$. Results are the average of 27 random observations, as previously stated.

\subsection{Surface stability during bioadhesion tests}

After plasma treatments, surfaces were conserved at atmospheric pressure and room temperature for 6 days. The water contact angles were measured daily, as described above, to evaluate surface stability.

To evaluate the impact of sterilization on surface hydrophobicity, treated surfaces were immersed in bleach (2.6\%) for 1 hour. Then, abundant washing and drying were performed as explained for the flow-cell sterilization process. The water contact angles were measured on the surface.

\subsection{Statistical analysis}

Statistical analyses of the data obtained for all experiments were carried out using the one-factor analysis variance (ANOVA). $\mathrm{P}$ values of $<0.01$ were considered as significant. Values were means \pm standard deviation.

\section{Results}

\subsection{Characterization of polycarbonate surfaces}

\subsubsection{Physico-chemical characterization}


The physico-chemical surface characteristics such as the contact angle of water and diiodomethane and the surface energy parameters of the untreated and treated polycarbonate surfaces are summarized in Table 1. The surface of the untreated PC was hydrophobic with a contact angle with water of $91^{\circ}$, a surface energy of $45 \mathrm{~mJ} / \mathrm{m}^{2}$, and a low polar surface component $\left(\gamma^{\mathrm{P}}\right)\left(0.4 \mathrm{~mJ} / \mathrm{m}^{2}\right)$. This result is congruent with previous studies ${ }^{29,51,52}$.

The plasma treatments modified the physico-chemical surface properties. The treatment by Ar plasma decreased the hydrophobicity (from $91^{\circ}$ to $18^{\circ}$ ). This result could be explained by the argon pressure used $\left(6,8.10^{-3} \mathrm{mbar}\right)$. Pedrosa et al. ${ }^{52}$ have observed a significant contact angle decrease for an argon pressure up to $4,8 \cdot 10^{-3}$ mbar. Similarly, the total surface energy was around $70 \mathrm{~mJ} / \mathrm{m}^{2}$ and the polar component $\left(\gamma^{\mathrm{P}}\right)$ was multiplied by 100 . The significant increase of the polar component has already been observed for different plasma treatments including $\mathrm{Ar}^{29,51}$.

The addition of a low amount of the functionalization gas $\mathrm{CF}_{4}(12 \%)$ did not modify the physico-chemical surface properties compared to Ar treatment: water contact angle and total surface energy were not different. The hydrophilicity of PC-Ar/CF $488 / 12$ was explained by the low amount of fluorine content $(2.7 \%)^{15}$, which was overcompensated by side effects associated with Ar plasma treatment as the surface oxidation ${ }^{30}$. However, a higher proportion of $\mathrm{CF}_{4}(88 \%)$ decreased the total surface energy from 45 to $20 \mathrm{~mJ} / \mathrm{m}^{2}$ for untreated PC and PC-Ar/ $\mathrm{CF}_{4}$ 12/88 without modification of the contact angle of water (91-93 around). $\mathrm{PC}-\mathrm{Ar} / \mathrm{CF}_{4} 12 / 88$ was the more hydrophobic of treated surfaces by the introduction of apolar functions.

\subsubsection{Concentrations of molecular functionalities of $P C$ surfaces}

The results of the chemical analysis of the surfaces are shown in Table 2. As expected, they indicate that the most abundant elements on the surfaces were carbon and oxygen. The $\mathrm{O} / \mathrm{C}$ ratio for untreated PC was 0.19 (0.17 in Kelar et al. $\left.{ }^{29}\right)$. After plasma treatments, the O/C ratios increased, which indicates more polar surfaces.

The Ar plasma-treated surface showed a higher amount of oxygen (24.0 versus $16.1 \%$ for PCAr and untreated PC respectively, $\mathrm{O} / \mathrm{C}$ ratio 0.34 ) and the presence of nitrogen and fluorine in low proportions. The presence of nitrogen could be explained by a post-oxidation of the substrate attributed to contamination from ambient air $^{29}$. 
The addition of functionalization gas as $\mathrm{CF}_{4}$ introduced only 2.7 and $8.8 \%$ of fluorine on the surface (depending on the composition of plasma) without any significant modification of oxygen and nitrogen fractions. Fluorinated PC surfaces presented in this paper showed low fluorine contents comparatively to $\mathrm{CF}_{4}$-plasma-treated surfaces proposed in the literature for bioadhesion modulation (47\% for $\mathrm{CF}_{4}$-plasma-treated PMMA and PDMS) ${ }^{30,32}$. Moreover, the most common fully fluorinated polymer (PTFE) has a fluorine content of $66.6 \%$.

The presence of other detected elements ( $\mathrm{Si}, \mathrm{Na}, \mathrm{Ca}$ ) must be assigned to side-pollution, either coming from the plasma chamber, analysis chamber or from external pollution since the XSP analysis being performed 2 or 3 days after the plasma treatment.

High-resolution XPS-spectra of C1s and O1s were realized. They revealed several peaks, and their attribution is mentioned in Figures 1 and 2.

The XPS analysis of untreated PC showed the presence of characteristic bonds $(\mathrm{C}=\mathrm{C}$ aromatics, $\mathrm{O}(\mathrm{C}=\mathrm{O}) \mathrm{O})$ but with proportions not corresponding to the theoretical calculation: a deficiency in carbonate function was observed (2.8\% instead of $6 \%$ ). This could be explained by the presence of additives (containing aromatic cycles and carbonyl functions) into and on the film.

The deconvolution of C1s peak of PC-Ar surface showed the disappearance of the peak at 285.3 $\mathrm{eV}$ (C-H aliphatic) associated with the degradation of methylene groups by the plasma. The increase of the binding energy (BE) at $286.0 \mathrm{eV}$ corresponds to an oxidation and a low incorporation of nitrogen. The formation of carboxylic acid and amide functions ( $\mathrm{BE}=288.1$ $\mathrm{eV})$ and a fragmentation of the carbonate fraction $(\mathrm{BE}=290.5 \mathrm{eV})$ were observed. Moreover, the increase of the peak at $292.8 \mathrm{eV}$ was probably explained by an increase of the aromatic character due to sputtering effects and aromatic additives exudation. The deconvolution of $\mathrm{O} 1 \mathrm{~s}$ peak showed a high increase of the carbonyl proportion associated with the apparition of carboxylic acids, esters or amide in low proportions in view of the chemical analysis (Table 2). $\mathrm{PC}$ surfaces treated by $\mathrm{Ar} / \mathrm{CF}_{4}$ plasma mainly showed the presence of fluorine in higher amount for the $\mathrm{Ar} / \mathrm{CF}_{4} 12 / 88$ than $\mathrm{Ar} / \mathrm{CF}_{4} 88 / 12$. The main bounds observed were -CF (BE=288.8 eV) and $-\mathrm{CF}_{2}(\mathrm{BE}=290.5 \mathrm{eV})$ rather than terminal $-\mathrm{CF}_{3}(\mathrm{BE}=292.8 \mathrm{eV})$. The decomposition of $\mathrm{O} 1 \mathrm{~s}$ peak confirmed the degradation of the carbonate bounds by the plasma treatment more loaded in $\mathrm{CF}_{4}$. Results were in line with other studies for which fluorinated polymer systems obtained by plasma treatments were investigated ${ }^{30}$. 
The four PC surfaces also showed different chemical surfaces. All surfaces were polar by the presence of carbonyl functions, but the introduction of $-\mathrm{CF},-\mathrm{CF}_{2}$ functions and to a lesser extent $-\mathrm{CF}_{3}$ decreased the surface polarity.

\subsubsection{Topography characterization}

Analysis of the topography of untreated and treated PC surfaces is presented in Figure 3. The data presented in Table 3 show that overall PC surfaces had a roughness between 0.8 and 2.9 $\mathrm{nm}$. No effect of Ar plasma was observed: the average roughness $\left(\mathrm{R}_{\mathrm{a}}\right)$ and the root mean square roughness $\left(\mathrm{R}_{\mathrm{ms}}\right)$ parameters measured for PC-Ar and untreated PC were not different. A light increase of the average roughness was observed in the presence of $\mathrm{Ar} / \mathrm{CF}_{4}$ treatment, but the difference was not significant. The roughness values observed were of the same order of magnitude as values cited in the literature in the case of activation of PC by atmospheric pressure plasma in ambient air ${ }^{29,53}$. Hence, it can be considered that all surfaces had the same average roughness. However, the topographic profiles of PC surfaces offered insights into their morphology: several sharp peaks (called protrudes) were observed for all surfaces. The PC$\mathrm{Ar} / \mathrm{CF}_{4} 12 / 88$ treatment promoted an increase in the protrude density. It was a sign of the bombarding "damage" that may go deep inside the first monolayers of the polymeric surface. This impact was dependent on the plasma parameters ${ }^{29,52}$.

\subsubsection{Surface stability during bioadhesion tests}

The plasma-treated surfaces were known to be unstable in aging ${ }^{29}$. To evaluate the stability of functionalization at atmospheric pressure, surface hydrophobicity was evaluated over time by contact angles with water measurements. After 6 days aging, variations of the contact angles of the different aged surfaces were negligible (around $6^{\circ}$ ). A weak increase of hydrophobicity was observed. This increase was relatively stable during storage of samples, which indicated relatively stable surfaces. These results were consistent with other studies ${ }^{14,31}$. Fluorocarbontreated PC surfaces were more stable than surfaces treated with other plasmas such as $\mathrm{N}_{2}$ or $\mathrm{O}_{2}{ }^{54}$.

The surface stability was evaluated by determining the water contact angles after immersion in a bleach solution $(2.6 \%, 1$ hour) and water (1 hour) to establish the surface properties faced by the marine organisms during bioadhesion tests. The sterilization step did not affect surface properties: the water contact angles were constant, and no significant difference from the data shown in Table 1 was observed. 


\subsection{Bioadhesion of micro-organisms to surfaces}

The effects of hydrophobicity, surface chemistry, and nanotopography were investigated on the anti-adhesive efficiency of polycarbonate surfaces against bacteria and microalgae.

\subsubsection{Bacterial response}

The surface characteristics of Paracoccus sp. 4M6 and Pseudoalteromonas sp. 5M6 cells were investigated earlier ${ }^{33}$. It was shown that Paracoccus sp. 4M6 was moderately hydrophilic $\left(\theta_{\text {water }}=53^{\circ}\right)$ and Pseudoalteromonas sp. 5M6 was more hydrophobic $\left(\theta_{\text {water }}=64^{\circ}\right)$. Paracoccus sp. 4M6 and Pseudoalteromonas sp. 5M6 possessed an isoelectric point of 2.2 and 3.15 respectively. Hence, both bacteria were negatively charged at alkaline $\mathrm{pHs}$ and more precisely at the $\mathrm{pH}$ of the seawater $(\mathrm{pH}=8)$ and in the conditions of our experiments. The average length of both bacteria was identical $(2 \mu \mathrm{m})$.

Bacterial adhesion was realized in a flow-cell system without flow for 2 hours of incubation in ASW. The adhesion was quantified by determining the percentage of bacterial coverage on surfaces. Results are shown in Figures 4 and 5. Both bacteria could adhere on PC surfaces. However, Pseudoalteromonas sp. 5M6, the more hydrophobic strain, adhered significantly $(\mathrm{p}<0.01)$ more on the hydrophobic untreated PC surface than the hydrophilic bacteria Paracoccus sp. 4M6.

Plasma treatments (Ar, $\mathrm{Ar} / \mathrm{CF}_{4} 88 / 12, \mathrm{Ar} / \mathrm{CF}_{4} 12 / 88$ ) modulated the colonization of surfaces by bacteria. However, the adhesion capacity of both bacteria was different. The treatment by Ar plasma (surface more oxygenated) decreased significantly $(\mathrm{p}<0.01)$ the adhesion of 5M6, whereas the decrease was lower and not significant for 4M6. The surface oxygenation influenced only the adhesion of the more hydrophobic cells.

Only PC-Ar/CF 4 88/12 decreased significantly ( $\mathrm{p}<0.01$ ) Paracoccus sp. 4M6 adhesion versus untreated PC, whereas no effect was observed for $\mathrm{PC}-\mathrm{Ar} / \mathrm{CF}_{4} 12 / 88$. In the case of Pseudoalteromonas sp. 5M6, the adhesion was significantly $(\mathrm{p}<0.01)$ lower on PC-Ar and PC$\mathrm{Ar} / \mathrm{CF}_{4} 12 / 88$, and no effect was observed on $\mathrm{PC}-\mathrm{Ar} / \mathrm{CF}_{4}$ 88/12. Once again, the behavior of both strains was opposite. However, both strains had the same adhesion capacity against PCAr: their coverage percentage was not significantly different $(\mathrm{p}>0.05)$. 


\subsubsection{Microalgal response}

Cylindrotheca closterium and Porphyridium purpureum are two micro-algal strains reported in biofouling studies ${ }^{34,35,55}$. C. closterium has a longitudinal shape with a length of $65 \pm 10 \mu \mathrm{m}$, whereas $P$. purpureum has a round shape $(5 \pm 0.5 \mu \mathrm{m})$.

Microalgal adhesion was realized in a flow-cell system without flow for 24 hours in ASW+F2. This amount of time and the presence of nutrients were more favorable to their adhesion on substrates ${ }^{41}$. The size difference of both strains precluded quantifying the adhesion by a simple coverage percentage. Hence, the adhesion was quantified by counting the adhered cells by unit of surface. Results are shown in Figures 6 and 7.

Both microalgae adhered on PC surfaces. Nevertheless, despite the fact that $C$. closterium took up more space than P. purpureum, the adhesion for C. closterium was significantly $(\mathrm{p}<0.01)$ higher than for P. purpureum. The adhesion of C. closterium was significantly decreased on PC-Ar and PC-Ar/CF4 12/88 whereas only the latter decreased significantly the adhesion of P. purpureum. PC-Ar/CF4 88/12 did not decrease the adhesion of both microalgae. However, a significant $(\mathrm{p}<0.01)$ increase of adhesion was observed for C. closterium.

\section{Discussion}

\subsection{Impact of material surface hydrophobicity on the adhesion of micro-organisms}

The impact of surface hydrophobicity can be evaluated by comparing PC and PC-Ar. The physico-chemical characterization results obtained for PC and PC-Ar clearly suggested that the topography and roughness of surfaces were almost identical: only the hydrophobicity differs. PC was hydrophobic whereas PC-Ar was hydrophilic with an increase of the oxygen rate in a low proportion. Generally, moderate hydrophobicity with a water contact angle of about $90^{\circ}$ produces the highest level of bacterial adhesion ${ }^{21}$. This was globally observed in this study. However, the influence of hydrophobicity was not clearly demonstrated: only two microorganisms out of four were sensitive to surface hydrophilicity: Pseudoalteromonas sp. 5M6 and C. closterium (45 and $80 \%$ adhesion inhibition respectively).

Pseudoalteromonas sp. 5M6, the more hydrophobic bacteria, adhered less on a hydrophilic surface whereas Paracoccus sp. 4M6 (moderate hydrophobicity) was not perturbed: the adhesion was not significantly different, regardless of the hydrophobicity of the surface. These results are not surprising. It is accepted that microbial adhesion depends strongly on the 
hydrophobic-hydrophilic structure of interacting surfaces ${ }^{56}$. Generally, hydrophobic bacteria adhere better and much more readily to hydrophobic surfaces whereas hydrophilic bacteria show less adhesion to hydrophobic surfaces ${ }^{23,57,58}$. However, it seems difficult to link bacterial surface hydrophobicity and bioadhesion to either a hydrophilic or hydrophobic substrate ${ }^{59}$.

For microalgae, only C. closterium diatom was significantly affected: the adhesion decreased on a hydrophilic surface. These results corresponded with published data for a short period of observation (less than 6h): multiple searches have shown stronger adhesion on hydrophobic surfaces $^{60,61,62,63,64}$. However, for longer observation times (3-4 days), results were more controversial. For example, Finlay et al. ${ }^{18}$ have shown the same adhesion regardless of the hydrophobicity. For $P$. purpureum, which is not a diatom, no data on the impact of hydrophobicity on adhesion is known.

Therefore, these different findings confirmed that the modulation of hydrophobicity alone is not sufficient to understand and so to modulate the adhesion of the majority of bacteria and microalgae.

\subsection{Impact of material surface hydrophobicity and fluorination on the adhesion of micro-organisms}

Comparing $\mathrm{PC}-\mathrm{Ar} / \mathrm{CF}_{4}$ 88/12 with $\mathrm{PC}-\mathrm{Ar}$ facilitates investigating the effect of fluorination alone on bacterial and microalgae adhesion. For a similar roughness and hydrophobicity, fluorination $(2.7 \%)$ increased significantly $(\mathrm{p}<0.01)$ the adhesion of micro-organisms for three strains out of four. Only one bacterial strain (Paracoccus sp. 4M6) showed a significant decrease of adhesion. Moreover, for Pseudoalteromonas sp. 5M6 and C. closterium, a significant $(\mathrm{p}>0.01)$ increase of the cell number was quantified.

Comparing hydrophilic PC-Ar/ $\mathrm{CF}_{4}$ 88/12 with hydrophobic untreated PC showed the impact of hydrophobicity associated with low fluorination (roughness and morphology were not different). Excepted for Paracoccus sp. 4M6, no significant impact was observed on the adhesion of micro-organisms. Moreover, for $C$. closterium, a significant ( $p>0.01$ ) increase of the cell number was quantified.

Whereas the $\mathrm{Ar} / \mathrm{CF}_{4}$ (88/12) plasma treatment showed an impact on the adhesion of microorganisms (decrease or increase of adhesion), these results did not explain the effect of 
fluorination on bioadhesion. There is no general trend that fluorination of PC leads to lower adhesion of micro-organisms. This result has already been reported for fluorinated PE and PS films ${ }^{31}$ : the anti-adhesion or the adhesion was found to be strain-dependent.

Nevertheless, some publications report a decrease of bioadhesion for fluorinated surfaces 39,65 . For example, fluorinated poly(dimethylsiloxane) surfaces (prepared by $\mathrm{CF}_{4}$ plasma) have shown a drastic adhesion reduction of two marine bacterial strains (Marinobacter hydrocarbonoclasticus and Cobetia marina) ${ }^{30}$. The electron-withdrawing effect of the fluorine groups probably plays a significant role in the bioadhesion of micro-organisms. However, the amounts of fluorine were significantly higher (up to 40\%) in all cases.

The hydrophobicity associated with fluorination was not sufficient to decrease the adhesion of micro-organisms.

\subsection{Impact of hydrophobicity, fluorination, and topography on the adhesion of micro- organisms}

$\mathrm{PC}-\mathrm{Ar} / \mathrm{CF}_{4}$ 12/88 was the more hydrophobic surface with a water angle contact similar to untreated PC but with a lower surface energy (20 versus $45 \mathrm{~mJ} / \mathrm{m}^{2}$ ). It contained a higher amount of fluorine (8.8\%) and in spite of an average surface roughness comparable to other surfaces, a more nanostructured architecture. Hence, this surface combined fluorination, protruded nanotopography, and low surface energy. This surface showed the best efficiency with three micro-organisms (one bacteria and two microalgae) out of four affected (from 65 to 90\% adhesion inhibition). Interestingly, it was the only surface decreasing $P$. purpureum adhesion ( $83 \%$ adhesion inhibition). To explain this remarkable activity, three hypotheses may be proposed.

First, the fluorination caused a bactericidal/algicidal effect. The bactericidal effects of fluoride have been reported ${ }^{15}$. Fluoride compounds from metal fluoride and HF or F- would inhibit the enzymes of micro-organisms ${ }^{66}$. However, this was contingent upon fluoride release, which was not supposed because the C-F bound degradation was unlikely. On the other hand, an electronwithdrawing effect of the $\mathrm{F}$ group would disturb the cell membrane function ${ }^{15,67}$. In our case, only one bacteria (Pseudoalteromonas sp. 5M6) was affected by the presence of fluorine (in the case of PC-Ar/CF $12 / 88$ with $8.8 \%$ of fluorine). Moreover, no quenching of fluorescence 
was observed for both microalgae, indicating no viability loss of adhered microalgae. Hence, the contribution of lethal effect, if it exists, probably remains restricted.

Second, PC-Ar/CF 4 12/88 showed the lowest surface energy $\left(20 \mathrm{~mJ} / \mathrm{m}^{2}\right)$. This surface energy was particularly interesting because for most organisms, including bacteria and diatoms, a surface free energy between $20-30 \mathrm{~mJ} / \mathrm{m}^{2}$ is related to the lowest bioadhesion ${ }^{6,68,69,70}$. Surfaces with low surface free energy within this range decreased the interaction between microorganisms and the substratum.

Third, PC-Ar/CF $12 / 88$ showed a nanoarchitectured surface. The influence of topography has been well researched in the last decade for some organisms, including bacteria and diatoms ${ }^{16,21,71,72}$. For bacteria, the presence of nanostructures involves two mechanisms: an antiadherent (unfavorable surface for attachment) mechanism and/or a bactericidal (that disrupt cells adsorbed onto the surface) mechanism ${ }^{73,74}$. Bacteria can use molecular features of their cell membrane as sensors and implement intracellular signaling pathways to sense the surface ${ }^{75}$. Bacterial attachment is influenced by the shape and size of the topographical features ${ }^{20}$. This can be explained by the contact area of the material surface with the bacterial cells that can either be increased or decreased depending on the topographical features on the nanostructures ${ }^{76}$. For example, Singh et al. ${ }^{77}$ have shown an increase of adhesion as roughness increases to approximately $20 \mathrm{~nm}$. Lorenzetti et al. $^{78}$ have shown the importance of nanostructures with fine asperities to reduce the contact area and hence the rate of bacterial adhesion. However, these results remain controversial ${ }^{74}$. Bacterial responses to topographical features are highly species- and strain-dependent, just like the type of material used ${ }^{79,80}$.

Although the effects of nanoroughness (at the hundred nanoscale) is documented on diatom (Amphora sp.) adhesion ${ }^{81}$, the role of nanostructuration $(<5 \mathrm{~nm})$ in the form of protrudes has never been reported. Knowing that the C. closterium diatoms tend to settle on the areas around the locations with protruded microtopographical features ${ }^{49}$, we may suppose that diatom settlement on nanoarchitectured surfaces was all the more physically disturbed.

\subsection{Importance of protruded nanotopography and low surface energy on anti- adhesive surface efficiency}

The efficiency of a PC-Ar/CF4 12/88 surface against three micro-organisms out of four can be explained by the combination of three parameters: fluorination, protruded nanotopography, and surface energy. Some authors have mentioned the synergetic effect of hydrophobicity, surface 
energy, and topography in anti-bioadhesion surfaces ${ }^{21,23}$. Functional groups presented on the surface determine the surface hydrophobicity. Hydrophobic surfaces cause low surface energy. In addition, roughness (at the nano- and/or micrometer scale) enhances water repellence and hydrophobicity ${ }^{82,83}$. The topography promotes the formation, in an aqueous medium, of a layer of air or microbubbles limiting bacterial and microalgae cell bioadhesion ${ }^{3,81}$. Nevertheless, the predominance of one parameter is still not clearly elucidated. For bacteria, some authors have suggested that the influence of the surface roughness dominates the influence of surface hydrophobicity ${ }^{84,85}$. Yuan et al. ${ }^{21}$ has shown the importance of the roughness and surface energy combination. Poncin-Epaillard et al. ${ }^{31}$ have pointed out the role of the dependence on the peaks and valley distribution at the bacteria dimension scale. Moreover, the spatial distribution of topological structures on a surface relative to bacterial size and shape are important parameters for bacterial adhesion ${ }^{86}$. For diatoms, surface topological structure and surface chemistry would be the two major factors involved in bioadhesion ${ }^{49}$.

Hence, our results suggested a significant role of protruded nanotopography associated with low surface energy to inhibit adhesion of bacteria and diatoms. This predominant effect of topography in comparison to hydrophobicity on bacterial attachment has already been demonstrated by Lorenzetti et al. ${ }^{78}$. Hence, the anti-adherent effect was probably the result of reduced contact between micro-organisms and the surface.

\section{Conclusions}

This study has shown that the modulation of bacteria and microalgal adhesion on a polymeric surface such as polycarbonate was possible by using $\mathrm{Ar} / \mathrm{CF}_{4}$ plasma treatment. Results confirmed that the modulation of hydrophobicity alone was not sufficient to control bacterial and microalgal adhesion. However, the combination of hydrophobicity and fluorination provided low surface energy while protruded nanotopography enhanced the surface antiadhesive activity. In this context, an efficient PC surface was obtained by using $\mathrm{Ar} / \mathrm{CF}_{4}(12 / 88)$ plasma treatment. This result is very important in the search for non-toxic antifouling surfaces for marine applications. However, it is possible to consider broadening the application domain to medical or agrofood surfaces to combat pathogenic micro-organisms and to propose other polymeric or inorganic surfaces combining low surface energy and protruded nanotopography.

\section{Acknowledgments}

The authors acknowledge the Université Bretagne Loire for financial support in this study. 


\section{References}

1. Artham T and Doble M (2009) Fouling and Degradation of Polycarbonate in Seawater: Field and Lab Studies. Journal of Polymer Environment 17: 1706180.

2. Kirstein IV, Wichels A, Krohne G and Gerdts G (2018) Mature biofilm communities on synthetic polymers in seawater - Specific or general? Marine Environmental Research 142: 147-154.

3. Legeay G, Coudreuse A, Poncin-Epaillard F, Herry JM and Bellon-Fontaine MN (2010) Surface Engineering and Cell Adhesion, Journal Adhesion Science and Technology 24: 2301-2322.

4. Schultz MP, Walker JM, Steppe CN and Flack KA (2015) Impact of diatomaceous biofilms on the frictional drag of fouling release coatings, Biofouling $\mathbf{3 1}$ : 9-10.

5. De Nys R and Guenther J (2009) The impact and control of biofouling in marine finfish aquaculture. In Advances in marine antifouling coatings and technologies. Woodhead Publishing Limited, pp 177-221

6. Callow JA and Callow ME (2011) Trends in the development of environmentally friendly fouling-resistant marine coatings. Nature Communications 2 : 244

7. McQuillan JS, Morris AK, Arundell M, Pascal R and Mowlem MC (2017) The anti-bacterial effect of an electrochemical anti-fouling method intended for the protection of miniaturized oceanographic sensors. Journal of Microbiological Methods 141: 63-66.

8. Agostini VO, Ritter MdoN, Macedo AJ, Muxagata E and Erthal F (2017) What determines sclerobiont colonization on marine mollusk shells? PLOS One 12: e0184745. 9. Schultz MP, Bendick JA, Holm ER and Hertel WM (2011) Economic impact of biofouling on a naval surface ship. Biofouling 27: 87-98.

10. Busscher HJ and Van der Mei HC (2012) How do bacteria known they are on a surface and regulate their response to an adhering state? PLOS Pathogens 8(1): e1002440.

11. Ozkan A and Berberoglu H (2013) Cell to substratum and cell to cell interactions of microalgae. Colloids and surfaces B: Biointerfaces 112: 302-309.

12. An YH and Friedman RJ (1998) Concise review of mechanisms of bacterial adhesion to biomaterials surfaces. Journal Biomedical Materials research 43: 338-348. 
13. Hori K and Matsumoto S (2010) Bacterial adhesion: from mechanism to control. Biochemical engineering Journal 48: 424-434.

14. Zhang X, Zhong Y, Zhang X, Li L and Yan Y (2013) Plasma and chromic acid treatments of polycarbonate surface to improve coating-substrate adhesion. Surface and Interface Analysis 45: 1893-1898.

15. Bao Q, Nishimura N, Kamata H, Furue K, Ono Y, Hosomi M andTerada A (2017) Antibacterial and antibiofilm efficacy of fluoropolymer coatings by a 2,3,5,6tetrafluoro-p-phenyldimethanol structure. Colloids and Surfaces B: biointerface 151: 363-371.

16. Wassmann T, Kreis S, Behr M and Buergers R (2017) The influence of surface texture and wettability on initial bacterial adhesion on titanium and zirconium oxide dental implants. International Journal of Implant Dentistry 3: 32.

17. Ozkan A and Berberoglu H (2013) Adhesion of algal cells to surfaces. Biofouling 29: 469-482.

18. Finlay JA, Callow ME, Ista LK, Lopez GP and Callow JA (2002) The influence of surface wettability on the adhesion strength of settled spores of the green alga enteromorpha and the diatom amphora. Integrative and Comparative Biology, 42: 11161122 .

19. Irving TE and Allen DG (2011) Species and material considerations in the formation and development of microalgal biofilm. Biotechnological products and process engineering, 92: 283-294.

20. Hsu L, Fang J, Borca-Tasciuc D, Worobo R, Moraru CI (2013) The effect of micro- and nanoscale topography on the adhesion of bacterial cells to solid surfaces, Applied Environmental Microbiology, 79: 2703-2712.

21. Yuan Y, Hays MP, Hardwidge PR, Kim J (2017) Surface characteristics influencing bacterial adhesion to polymeric substrates, RSC Advances, 7: 14254-14261. 22. Waugh DG, Toccaceli C, Gillett AR, Chi-Ho Ng, Hodgson SD and Lawrence J (2016) Surface treatments to modulate bioadhesion: A critical review, Reviews of adhesion and Adhesives, 4: 69-103.

23. Bazaka K, Jacob MV, Crawford RJ and Ivanova EP (2011) Plasma-assisted surface modification of organic biopolymers to prevent bacterial attachment. Act Biomaterialia, 7: 2015-2028. 
24. Poncin-Epaillard F, Vrlinic T, Debarnot D, Mozetic M, Coudreuse A, Legeay G, El Moualij B and Zorzi W (2012) Surface Treatment of Polymeric Materials Controlling the Adhesion of Biomolecules. Journal of Functionnal Biomaterials 3: 528-543.

25. Bhatt S, Pulpytel J, Arefi-Khonsari F (2015) Low and atmospheric plasma polymerisation of nanocoatings for bio-applications. Surface Innovations 3: 63-83.

26. Desmet T, Morent, R, De Geyter N, Leys C, Schacht E and Dubruel P (2009) Nonthermal plasma technology as a versatile strategy for polymeric biomaterials surface modification: review, Biomacromolecules 10: 2351-2378.

27. Siow KS, Britcher L, Kumar S and Griesser HJ (2006) Plasma Methods for the Generation of Chemically reactive surfaces for Biomolecules Immobilization and cell colonization - A review. Plasma Processes and polymers 3: 392-418.

28. Wang IW, Anderson JM, Jacobs MR and Marchand RE (1995) Adhesion of Staphylococcus epidermidis to biomedical polymers: contributions of surface thermodynamics and hemodynamics shear condition. Journal Biomedical Materials Research 29: 485-93.

29. Kelar J, Shekargoftar M, Krumpolec R and Homola T (2018) Activation of polycarbonate (PC) surfaces by atmospheric pressure plasma in ambient air. Polymer Testing 67: 428-434.

30. Cordeiro AL, Nitschke M, Janke A, Helbig R, D’Souza F, Donelly GT, Willemsen PR and Werner C (2009) Fluorination of poly(dimethylsiloxane) surfaces by low pressure $\mathrm{CF}_{4}$ plasma - physicochemical and antifouling properties Express Polymer Letters 3: 70-83.

31. Poncin-Epaillard F, Herry JM, Marmey P, Legeay G, Debarnot D and BellonFontaine MN (2013) Elaboration of highly hydrophobic polymeric surface - a potential strategy to reduce the adhesion of pathogenic bacteria? Materials Science and Engineering C. 33: 1152-1161.

32. Eloy R, Parrat D, Tran Min Duc, Legeay G and Bechetoille MD (1993) In vitro evaluation of inflammatory cell response after $\mathrm{CF}_{4}$ plasma surface modification of poly(methyl methacrylate) intraocular lenses. Journal of Cataract \& refractive Surgery 19: $364-370$.

33. Grasland B, Mitalane J, Briandet R, Quemener E, Meylheuc T, Linossier I, Vallée-réhel K and Haras D (2003) Bacterial biofilm in seawater: cell surface properties of early-attached Marine Bacteria. Biofouling 19: 307-313. 
34. Briand JF, Djeridi I, Jamet D, Coupé S, Bressy C, Molmeret M, Le Berre B, Rimet F, Bouchez A and Blache Y (2012) Pioneer marine biofilms on artificial surfaces including antifouling coatings immersed in two contrasting French Mediterranean coast sites. Biofouling 28: 453-463.

35. Zargiel KA and Swain GW (2014) Static vs dynamic settlement and adhesion of diatoms to ship hull coatings. Biofouling 30: 115-129.

36. Chen CL, Maki JS, Rittschof D and Teo SLM (2013) Early marine bacterial biofilm on a copper-based antifouling paint. International Biodeterioration \& Biodegradation 83: 71-76.

37. Camps M, Barani A, Gregori G, Bouchez A, Le Berre A, Bressy C, Blanche Y and Briand JF (2014) Antifouling Coatings influence both abundance and community structure of colonizing biofilms: a case study in the northwestern Mediterranean sea. Applied and Environmental Microbiology 80: 16, 4821-4831.

38. Hadfield MG (2011) Biofilms and Marine Invertebrate larvae: what bacteria produce that larvae use to choose settlement sites. Annual Review of Marine Science 3: 453-470.

39. Dobretsov S and Thomason JC (2011) The development of marine biofilms on two commercial non-biocidal coatings: a comparison between silicone and fluoropolymer technologies. Biofouling 27: 869-880.

40. Dheilly A, Soum-Soutéra E, Klein GL, Bazire A, Compère C, Haras D and Dufour A (2010) Applied and Environmental Microbiology 76: 3452-3461.

41. Le Norcy T, Faÿ F, Zea Obando C, Hellio C, Réhel K and Linossier I (2019) A new method for evaluation of antifouling activity of molecules against microalgal biofilms using confocal laser scanning microscopy-microfluidic flow-cells. International Biodeterioration Biodegradation 139: 54-61.

42. Fanesi A, Paule A, Bernard O, Briandet R and Lopes F (2019) The architecture of Monospecific Microalgae Biofilms. Microorganisms 7: 352.

43. Camps M, Briand JF, Guentas-Dombrowsky L, Culioli G, Bazire A and Blache Y (2011) Antifouling activity of commercial biocide vs. natural and natural-derived products assessed by marine bacteria adhesion bioassay. Marine Pollution Bulletin 62 : 1032-1040.

44. Linares D, Bottzeck O, Pereira A, Praud-Tabariès A and Blache Y (2011) Designing 2-aminoimidazole alkaloids analogs with anti-biofilm activities: Structure- 
activities relationships of polysubstituted triazoles. Bioorganic \& Medicinal Chemistry Letters 21: 6751-6755.

45. Sall C, Ayé M, Bottzeck O, Praud A and Blache Y (2018) Towrads smart biocide-free anti-biofilm strategies: Click-based synthesis of cinnamide analogues as anti-biofilm compounds against marine bacteria. Bioorganic \& Medicinal chemistry Letters 28: 155-159.

46. Le Norcy T, Niemann H, Proksch P, Linossier I, Vallée-Réhel K, Hellio C and Faÿ F (2017) Anti-biofilm effect of biodegradable coatings based on hemibastadin derivative in marine environment. International Journal Molecular Sciences 18: 1520. 47. Moodie LWX, Cervin G, Trepos R, Labriere C, Hellio C, Pavia H and Svenson J (2018) Design and Biological Evaluation of Antifouling Dihydrostilbene Oxime Hybrids. Marine Biotechnology 20: 257-267.

48. Scardino AJ (2011) Mini-review: biomimetic models and bioinspired surfaces for fouling control Biofouling, 27: 73-86.

49. Chen X, He X, Suo X, Huang J, Gong Y, Liu G and Li H (2016) Effect of surface topological structure and chemical modification of flame sprayed aluminum coatings on the colonization of Cylindrotheca closterium on their surfaces Applied Surface Science 388: 385-391.

50. Sullivan T and Regan F (2017) Marine diatom settlement on microtextured materials in static field trials, Journal of Materials Sciences 52: 5846-5856.

51. Kitova S, Minchev M and Danev G (2005) RF Plasma treatment of polycarbonate substrate, Journal of Optoelectronics and Advanced Materials, 7: 26072612.

52. Pedrosa P, Chappé JM, Fonseca C, Machado AV, Nobrega JM, Vaz F (2010) Plasma Surface Modification of Polycarbonate and Poly(propylene) substrate for Biomedical electrodes. Plasma Processes and Polymers 7: 676-686.

53. Yaghoubi H and Taghavinia N (2011) Surface chemistry of atmospheric plasma modified polycarbonate substrates. Applied Surface Science 23: 9836-9839.

54. Hegemann D, Bruner H and Oehr C (2003) Plasma treatment of polymers for surface and adhesion improvement. Nuclear Instruments and Methods in Physics Research B 208: 281-286.

55. Jellali R, Campistron I, Pasetto P, Laguerre A, Gohier F, Hellio C, Pilard JF and Mouget JL (2013) Antifouling activity of novel polyisoprene-based coatings made from 
photocurable natural rubber derived oligomers. Progress in Organic Coatings 76: 1203 1214.

56. Liu Y, Yang SF, Li Y, Xu H, Qin L and Tay JH (2004) The influence of cell and substratum surface hydrophobicities on microbial attachment. Journal of biotechnology 110: $251-256$.

57. Teixeira P and Oliveira R (1999) Influence of surface characteristics on the adhesion of Alcaligenes denitrificans to polymeric surfaces. Journal Adhesion Science Technology 13: 1287-1294.

58. Bayoudh A, Othmane A, Bettaieb F, Bakhrouf A, Ben Ouada H and Ponsonnet L (2006) Quantification of the adhesion free energy between bacteria and hydrophobic and hydrophilic substrata. Materials Science and Engineering 26: 300-305.

59. Cerca N, Pier GB, Vilanova M, Oliveira R and Azeredo J (2005) Quantitative analysis of adhesion and biofilm formation on hydrophilic and hydrophobic surfaces of clinical isolates of Staphylococcus epidermidis. Research in Microbiology 156: 506514.

60. Schilp S, Kueller A, Rosenhahn A, Grunze M, Pettitt M, Callow ME and Callow J (2007) Settlement and adhesion of algal cells to hexa(ethylene glycol)-containing selfassembled momolayers with systematically changed wetting properties. Biointerphases 2: $143-150$.

61. Stanley M and Callow J (2007) Whole cell adhesion strength of morphotypes and isolates of Phaedactylum tricornutum (Bacillariophycea). European Journal Phycology 42: 191-197.

62. Holland R, Dugdale TM, Wetherbee R, Brennan AB, Finlay JA, Callow JA and Callow ME (2004) Adhesion and motility of fouling diatoms on a silicone elastomer. Biofouling 20: 323-329.

63. Thompson SE, Taylor AR, Brownlee C, Callow M and Callow JA (2008) The role of nitric oxide in diatom adhesion in relation to substratum properties, Journal of Phycology 44: 967-976.

64. Klein G, Pierre G, Bellon-Fontaine MN, Zhao JM, Breret M, Maugard T and Graber M (2014) Marine diatom Navicula jeffreyi from biochemical composition and physico-chemical surface properties to understanding the first step of benthic biofilm formation. Journal Adhesion Science and Technology 28: 1739-1753.

65. Lepoittevin B, Bedel S, Dragoé D, Bruzaud S, Barthés-Labrousse MG, Mazerat S, Herry JM, Bellon-Fontaine MN, Roger Ph (2015) Antibacterial surfaces obtained 
through dopamine and fluorination functionalizations. Progress in Organic Coatings 82: $17-25$.

66. Marquis RE, Clock SA, Mota-Meira M (2003) Fluoride and organic weak acids as modulators of microbial physiology. FEMS Microbiology reviews. 26: 493-510.

67. Limban C and Chifiriuc MC (2011) Antibacterial activity of new dibenzoxepinone oximes with fluorine and trifluoromethyl group substituents. International Journal Molecular Sciences. 12: 6432-6444.

68. Pereni CI, Zhao Q, Liu Y and Abel E (2006) Surface free energy effect on bacterial retention. Colloids and Surfaces B: Biointerfaces. 48: 143-147.

69. Li Y, Gao YH, Li XS and Yang JY and Que GH (2010) Influence of surface free energy on the adhesion of marine benthic diatom Nitzschia closterium MMDL533. Colloids and Surface B : interfaces, 75: 550-556.

70. Brady RF (2000) Clean hulls without poisons: devising and testing nontoxic marine coatings. Journal Coatings Technology 72: 45-56.

71. Ferrari M and Benedetti A (2015) Superhydrophobic surfaces for applications in seawater. Advances in Colloid and Interface Science 222: 291-304.

72. Xiao L, Finlay JA, Röhrig M, Mieszkin S, Worgull M, Hölscher H, Callow JA, Callow ME, Grunze M and Rosenhahn A (2018) Topographic cues guide the attachment of diatom cells and algal zoospores. Biofouling 34: 86-97.

73. Elbourne A, Crawford RJ and Ivanova EP (2017) Nano-structured antimicrobial surfaces: from nature to synthetic analogues. Journal Colloid and Interface Science 508: 603-616

74. Modaresifar K, Azizian S, Ganjian M, Fratila-Apachitei E and Zadpoor A (2018) Bactericidal effects of nanopatterns : A systematic review. Acta Biomaterialia 83: 2936

75. Otto K, Norbeck J, Larsson T, Karlsson KA and Hermansson M (2001) Adhesion of Type 1-Fimbriated Escherichia coli to abiotic surfaces leads to altered composition of outer membrane proteins. Journal of Bacteriology 183: 2445-2453.

76. Wu S, Zuber F, Maniura-Weber K, Brugger J and Ren Q (2018) Nanostructured surface topographies have an effect on bactericidal activity. Journal Nanobiotechnology 16: 20 .

77. Singh AV, Vyas V, Patil R, Sharma V, Scopelliti PE, Bongiorno G, Podesta A, Lenardi C, Gade WN, Milani P (2011) Quantitative characterization of the influence of 
the nanoscale morphology of nanostructured surfaces on bacterial adhesion and biofilm formation. PLOS one 6: e25029.

78. Lorenzetti M, Biglino D, Novak S and Kobe S (2014) Photoinduced properties of nanocrystalline $\mathrm{TiO}_{2}$-anatase coating on Ti-based bone implants. Materials Science and Engineering C 37: 390-398.

79. Anselme K, Davidson P, Popa AM, Giazzon M, Liley and Ploux L (2010) The interaction of cells and bacteria with surfaces structured at the nanometers scale. Acta Biomaterialia 6: 3824-3848.

80. Yoda I, Koseki H, Tomita M, Shida T, Horiuchi H, Sakoda H and Osaki M (2014) Effect of surface roughness of biomaterials on Staphylococcus epidermidis adhesion BMC microbiology 14: 234.

81. Scardino AJ, Zhang H, Cookson DJ, Lamb DJ and de Nys R. (2009) The role of nano-roughness in antifouling. Biofouling 25: 757-767.

82. Oner D, McCarthy J (2000) Ultrahydrophobic surfaces. Effects of topography length scales on wettability. Langmuir 16: 7777-7782.

83. Feng L, Li S, Li Y, Li H, Zhang L, Zhai J, Song Y, Liu B, Jiang L and Zhu D (2002) Super-hydrophobic surfaces: from natural to artificial. Advanced materials 14: $1857-1860$

84. Quirynen M, Bollen CML, Vandekerckhove C, Dekeyser D, Papaionannou W and Eyssen H (1995) Full- vs. Partial-mouth disinfection in the treatment of periodontal infections: short- term clinical and microbiological observations. Journal Dental Research 74: 1459-1467.

85. Tang H, Cao T, Wang A, Liang X, Salley SO, Mc Allister II JP and Simon Ng KY (2007) Effect of surface modification of silicone on Staphylococcus epidermidis adhesion and colonization. J Biomedical Materials Research 80A: 885-894.

86. Kelleher SM, Habimana O, Lawler J, O’Reilly B, Daniels S, Casey E and Cowley A (2016) Cicada Wing surface topography: an investigation into the bactericidal properties of nanostructural features. ACS Apl. Mater. Interfaces 8: 1496614974.

Table 1. Contact angle and surface free energy values of untreated and plasma-treated PC surfaces. $\gamma^{\mathrm{D}}$ : dispersion component, $\gamma^{\mathrm{P}}$ : polar component 


\begin{tabular}{|l|l|l|l|l|l|}
\hline$\theta\left(^{\circ}\right)$ & Water & Diiodomethane & $\begin{array}{l}\gamma^{\text {total }} \\
\left(\mathrm{mJ} / \mathrm{m}^{2}\right)\end{array}$ & $\gamma^{\mathrm{D}}\left(\mathrm{mJ} / \mathrm{m}^{2}\right)$ & $\gamma^{\mathrm{P}}\left(\mathrm{mJ} / \mathrm{m}^{2}\right)$ \\
\hline $\begin{array}{l}\text { Untreated } \\
\text { surface }\end{array}$ & $91 \pm 1$ & $30 \pm 1$ & $45 \pm 1$ & $45 \pm 1$ & $0,4 \pm 0,1$ \\
\hline $\begin{array}{l}\text { PC-Ar } \\
\text { PC-Ar/CF }\end{array}$ & $18 \pm 2$ & $47 \pm 2$ & $70 \pm 2$ & $25 \pm 1$ & $44 \pm 1$ \\
\hline $88 / 12$ & $44 \pm 2$ & $68 \pm 2$ & $27 \pm 1$ & $41 \pm 1$ \\
\hline $\begin{array}{l}\mathrm{PC}-\mathrm{Ar} / \mathrm{CF}_{4} \\
12 / 88\end{array}$ & $93 \pm 3$ & $82 \pm 2$ & $20 \pm 2$ & $6 \pm 2$ & $14 \pm 2$ \\
\hline
\end{tabular}

Table 2: Atomic fraction of elements (in percentage) detected by XPS on the untreated and plasma-treated polycarbonate surfaces.

\begin{tabular}{|c|c|c|c|c|c|c|}
\hline$\%$ & $\mathrm{C}$ & $\mathrm{O}$ & $\mathrm{N}$ & $\mathrm{F}$ & $\mathrm{O} / \mathrm{C}$ & Others \\
\hline Untreated PC & $\begin{array}{l}82.2 \pm \\
4.1\end{array}$ & $\begin{array}{l}16.1 \quad \pm \\
0.8\end{array}$ & 0 & 0 & $\begin{array}{l}0.19 \quad \pm \\
0.02\end{array}$ & $\mathrm{Si}(1.7)$ \\
\hline $\mathrm{PC}-\mathrm{Ar}$ & $\begin{array}{l}71.0 \quad \pm \\
3.5\end{array}$ & $\begin{array}{l}24.0 \quad \pm \\
1.2\end{array}$ & $1.6 \pm 0.7$ & 0.5 & $\begin{array}{l}0.34 \quad \pm \\
0.03\end{array}$ & $\begin{array}{l}\mathrm{Si}(1.5), \mathrm{Na} \\
(2.4)\end{array}$ \\
\hline $\begin{array}{l}\mathrm{PC}-\mathrm{Ar} / \mathrm{CF}_{4} \\
88 / 12\end{array}$ & $\begin{array}{l}74.8 \quad \pm \\
3.7\end{array}$ & $\begin{array}{l}20.2 \quad \pm \\
1.0\end{array}$ & $1.6 \pm 0.8$ & $2.7 \pm 0.1$ & $\begin{array}{l}0.27 \quad \pm \\
0.02\end{array}$ & $\mathrm{Na}, \mathrm{Ca}(0.7)$ \\
\hline $\begin{array}{l}\mathrm{PC}-\mathrm{Ar} / \mathrm{CF}_{4} \\
12 / 88\end{array}$ & $\begin{array}{l}59.6 \quad \pm \\
2.9\end{array}$ & $\begin{array}{l}23.3 \quad \pm \\
1.2\end{array}$ & $1.1 \pm 0.1$ & $8.8 \pm 0.4$ & $\begin{array}{l}0.39 \quad \pm \\
0.02\end{array}$ & $\mathrm{Si}(7.0)$ \\
\hline
\end{tabular}

Table 3: AFM surface roughness analysis of the surfaces

\begin{tabular}{|l|l|l|l|l|}
\hline $\begin{array}{l}\text { Surfaces } \\
\text { roughness (nm) }\end{array}$ & $\begin{array}{l}\text { Untreated } \\
\text { PC }\end{array}$ & PC-Ar & $\begin{array}{l}\text { PC- } \\
\text { Ar/CF } 4\end{array}$ & $\begin{array}{l}\text { PC-Ar/CF } 4 \\
12 / 88\end{array}$ \\
\hline $\mathrm{R}_{\mathrm{a}}$ & 0.8 & 0.8 & 1.2 & 2.9 \\
\hline $\mathrm{R}_{\mathrm{ms}}$ & 3.1 & 2.7 & 2.6 & 4.7 \\
\hline
\end{tabular}



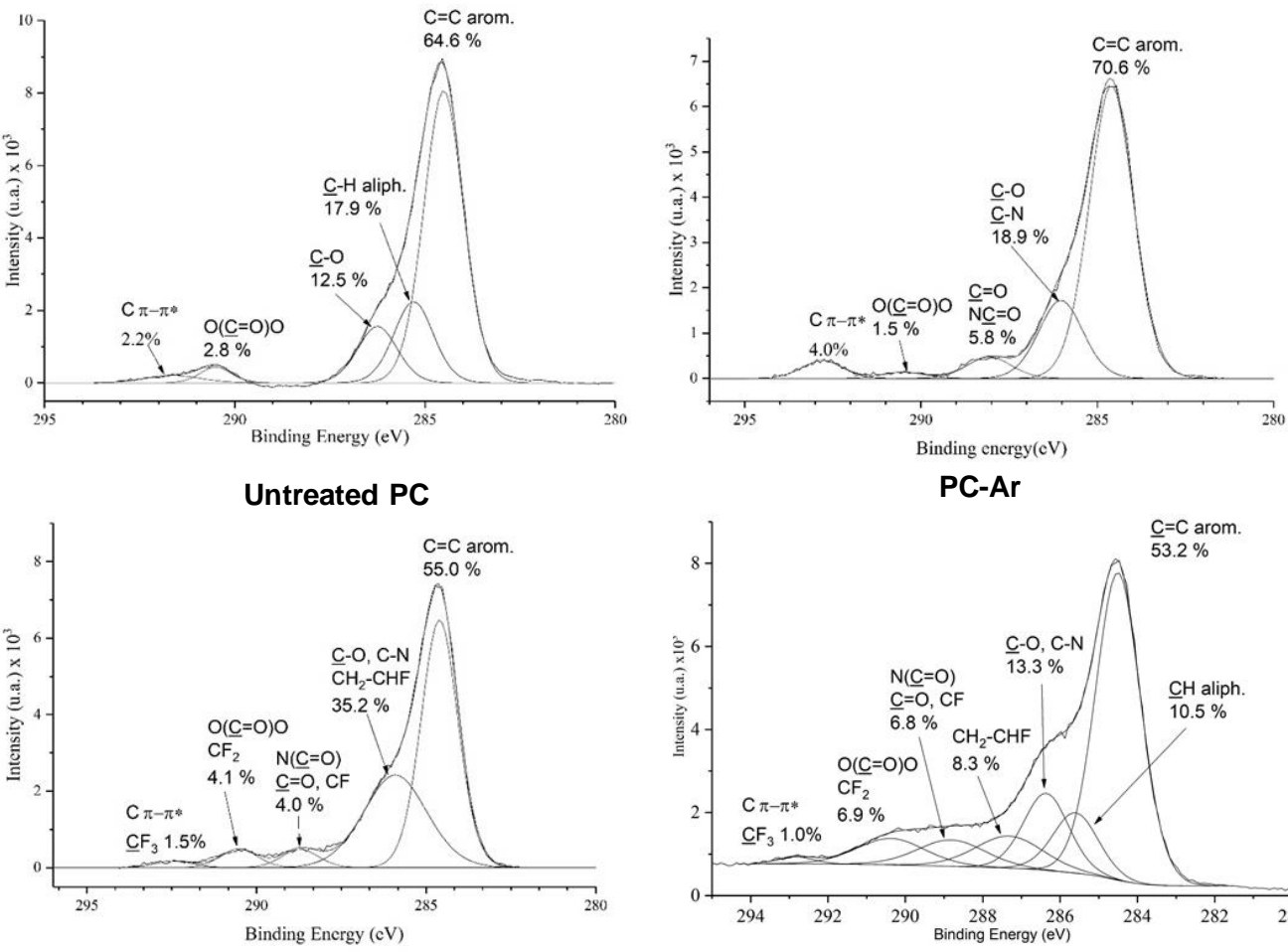

$\mathrm{PC}-\mathrm{Ar} / \mathrm{CF}_{4}$

88/12

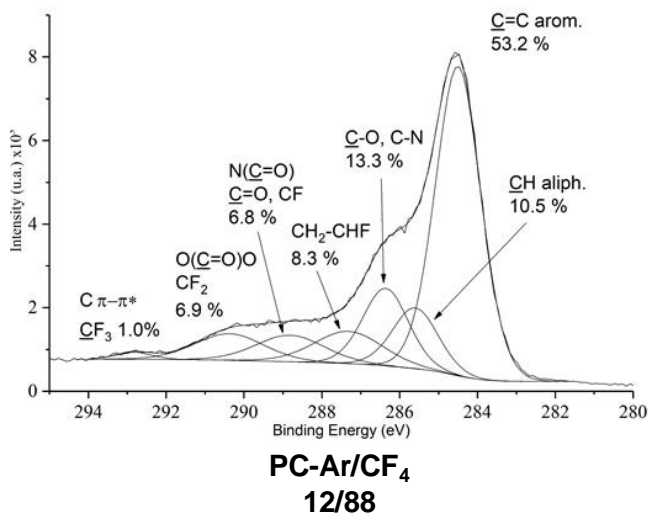

Figure 1: XPS-spectra (C1s peak) of untreated PC and PC plasma-treated polycarbonate surfaces.

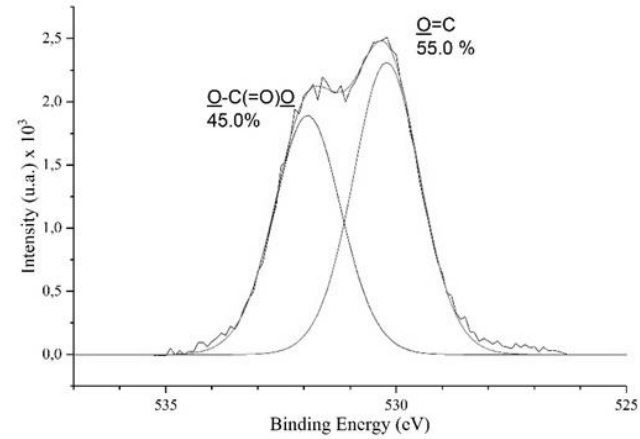

Untreated PC





PC-Ar

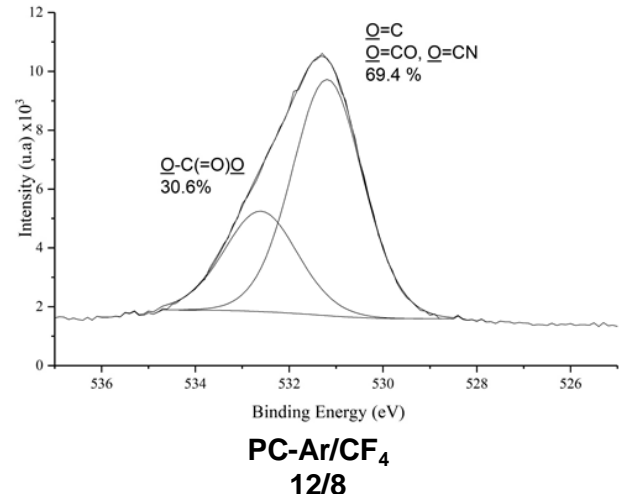


Figure 2: XPS-spectra (O1s peak) of untreated PC and PC plasma-treated polycarbonate surfaces.

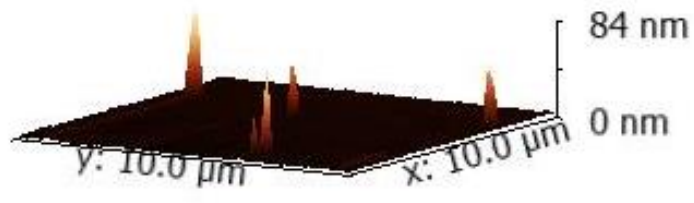

Untreated PC

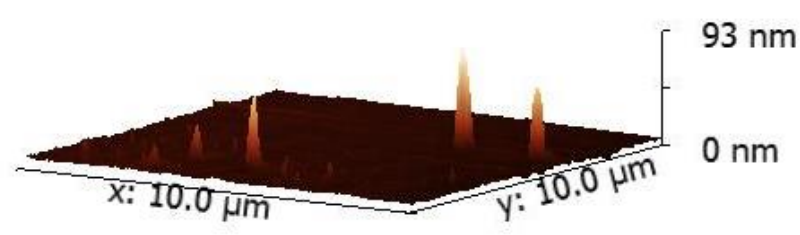

$\mathrm{PC}-\mathrm{Ar} / \mathrm{CF}_{4} 88 / 12$

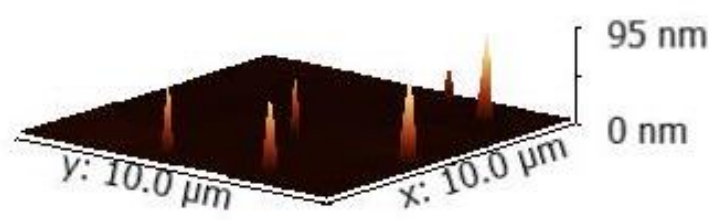

$\mathrm{PC}-\mathrm{Ar}$

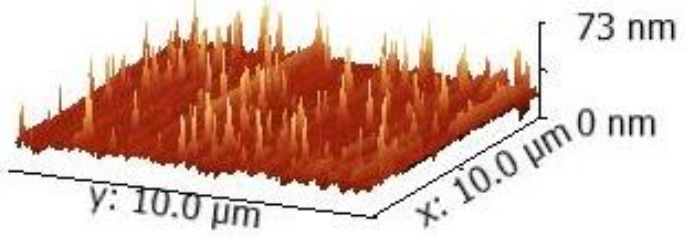

$\mathrm{PC}-\mathrm{Ar} / \mathrm{CF}_{4} 12 / 88$

Figure 3: Surface topography of surfaces observed by AFM

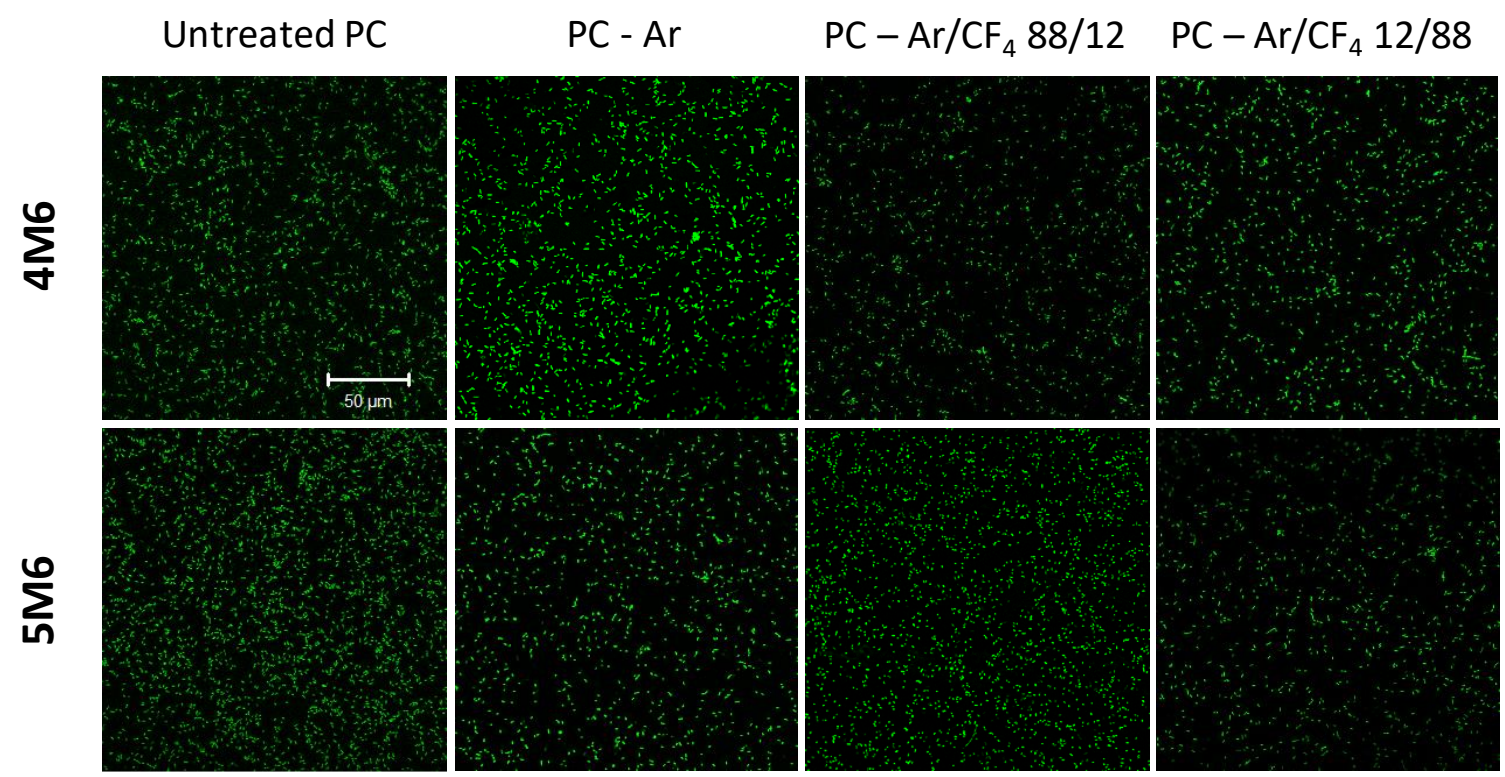

Figure 4: Confocal laser scanning microscopy observations of the bacterial adhesion with syto $9^{\circledR}$ ( $\square$ excitation: $488 \mathrm{~nm}, \square$ emission: $493-533 \mathrm{~nm}$ ) after $2 \mathrm{~h}$ on untreated and plasmatreated PC. The scale is the same for all micrographies. 


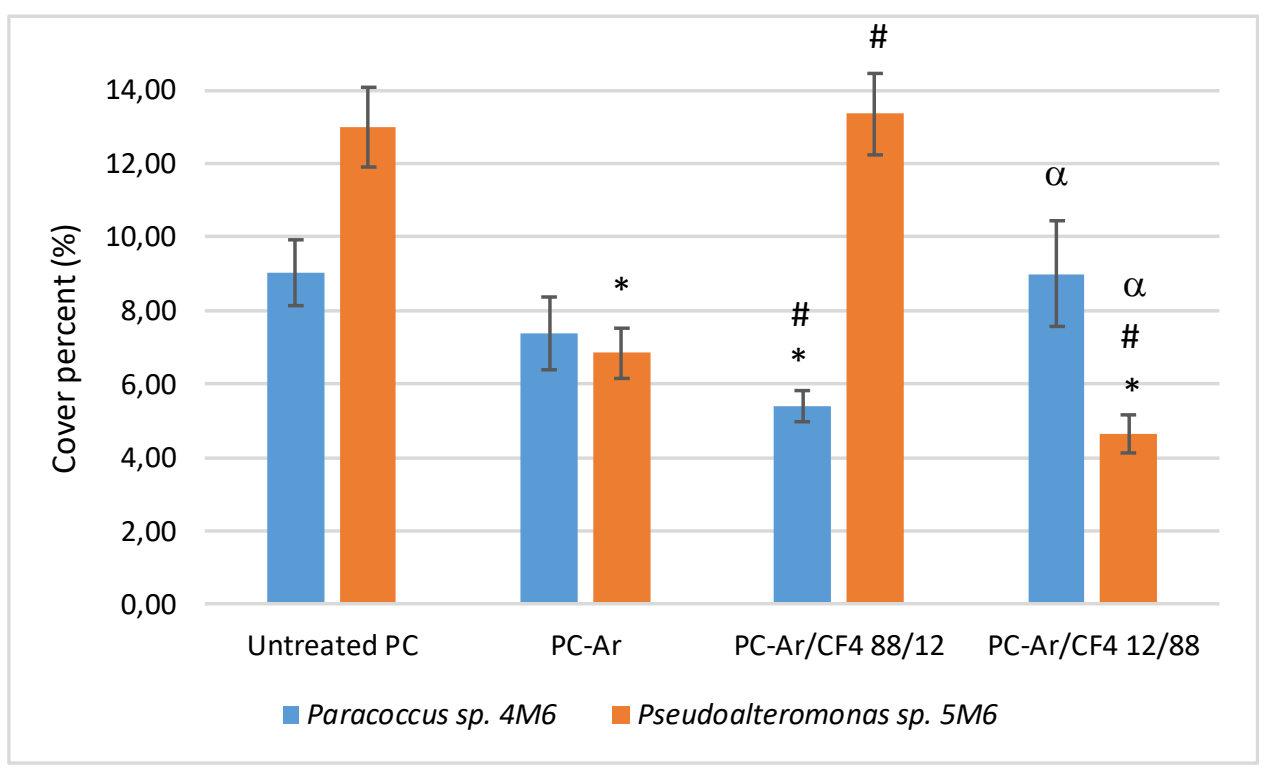

Figure 5: Adhesion of marine bacteria on untreated and plasma-treated PC. *, significant difference $(\mathrm{p}<0.01)$ from untreated PC. \#, significant difference $(\mathrm{p}<0.01)$ from PC-Ar. $\square$, significant difference $(\mathrm{p}<0.01)$ from $\mathrm{PC}-\mathrm{Ar} / \mathrm{CF}_{4} 88 / 12$

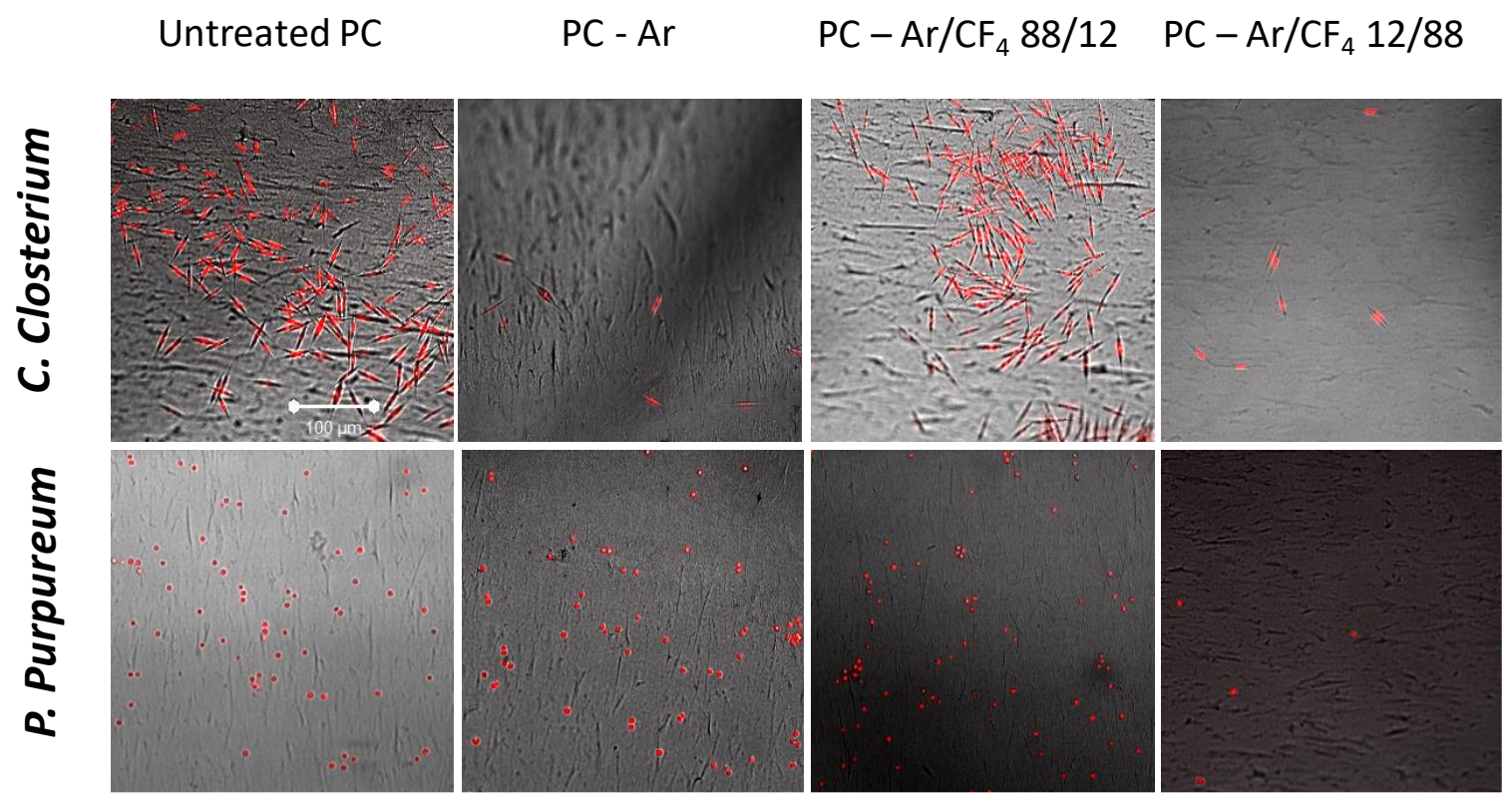

Figure 6: Confocal laser scanning microscopy observations of the microalgal adhesion after 24 $\mathrm{h}$ on untreated and plasma-treated PC. Cells were detected by their auto-fluorescence ( $\square$ excitation: $633 \mathrm{~nm}$, $\square$ emission: 638-688 nm). The scale is the same for all micrographies. 


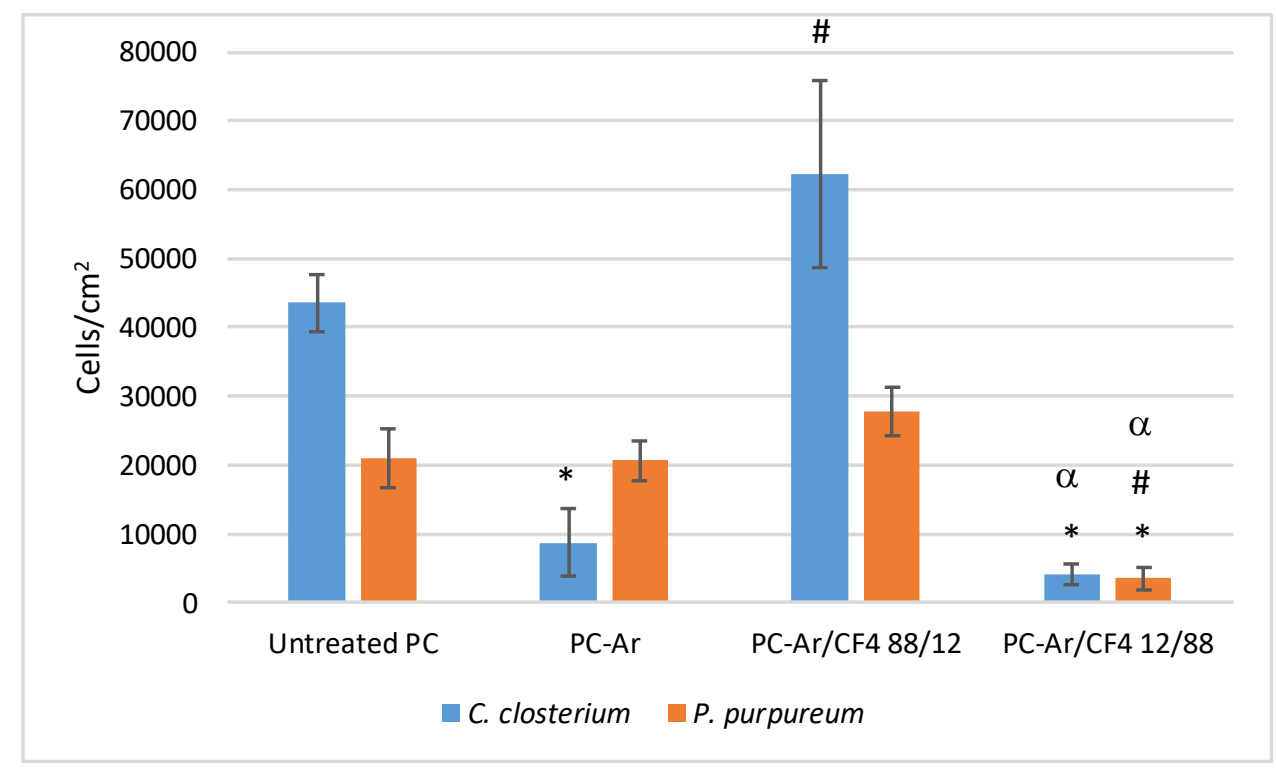

Figure 7: Adhesion of microalgae on untreated and treated PC. *, significant difference $(\mathrm{p}<0.01)$ from untreated PC. \#, significant difference $(\mathrm{p}<0.01)$ from PC-Ar. $\square$, significant difference $(\mathrm{p}<0.01)$ from $\mathrm{PC}-\mathrm{Ar} / \mathrm{CF}_{4} 88 / 12$ 